\title{
p53 domains: identification and characterization of two autonomous DNA-binding regions
}

\author{
Yun Wang, Michael Reed, Pin Wang, Judith E. Stenger, Gregory Mayr, Mary E. Anderson, \\ John F. Schwedes, and Peter Tegtmeyer ${ }^{1}$ \\ Department of Microbiology, State University of New York, Stony Brook, New York 11794 USA
}

\begin{abstract}
We have investigated the DNA-binding, oligomerization, and trans-activation functions of isolated segments of murine p53. We find that p53 has two autonomous DNA-binding regions. One domain, from amino acid 280 to 390, forms stable tetramers and binds DNA nonspecifically. The biological significance, if any, of this DNA-binding activity is not known. A second domain, from amino acid 80 to 290 , does not form stable tetramers under stringent conditions but binds DNA both specifically and nonspecifically. The specific DNA-binding function of $\mathbf{p 5 3}$, therefore, resides in the highly conserved central region of the protein and does not require stable tetramerization. Amino acids 1-290, which include both the specific DNA-binding domain and the amino-terminal acidic region, activate a p53-specific promoter in vivo. This finding strongly argues that the DNA-binding activity of p53 segment $80-290$ is physiologically significant. The role of tetramerization in $\mathbf{p} 53$ function remains to be determined.
\end{abstract}

[Key Words: p53; domains; tetramers; DNA binding; trans-activation]

Received August 18, 1993; revised version accepted September 23, 1993.

The p53 gene suppresses cell proliferation (Eliyahu et al. 1989; Finlay et al. 1989; Hinds et al. 1989), and the loss of p53 function is associated with a broad spectrum of human cancers (Hollstein et al. 1991; Levine et al. 1991). Although the mechanism of action of p53 is not well understood, many studies have implicated p53 in the regulation of transcription. The protein has an acidic amino-terminal region and binds to specific DNA sequences (Bargonetti et al. 1991; Kern et al. 1991; El-Deiry et al. 1992; Funk et al. 1992). When a DNA-binding site for $\mathrm{p} 53$ is placed upstream from a basal promoter, $\mathrm{p} 53$ strongly activates transcription of a variety of reporter genes in vivo and in vitro (Farmer et al. 1992; Funk et al. 1992; Kern et al. 1992). p53 also activates transcription of several natural promoters (Weintraub et al. 1991; Kastan et al. 1992; Zambetti et al. 1992; Barak et al. 1993; Wu et al. 1993). Paradoxically, p53 represses the transcription in vivo of a number of genes that have no apparent p53 binding sites (Ginsberg et al. 1991; Mercer et al. 1991; Santhanam et al. 1991; Shiio et al. 1992). A number of investigators have shown that $\mathrm{p} 53$ interacts with TBP (Seto et al. 1992; Liu et al. 1993; Mack et al. 1993; Ragimov et al. 1993; Truant et al. 1993), the TATA-binding protein that initiates the formation of transcriptional complexes at many promoters. The binding of $\mathrm{p} 53$ to TBP may activate or repress tran-

${ }^{1}$ Corresponding author. scription depending on the context of the promoter (Seto et al. 1992). p53 has also been shown to form tetramers (Milner et al. 1991; Stenger et al. 1992; Sturzbecher et al. 1992; Friedman et al. 1993), and several investigators have suggested that oligomerization may contribute to p53-DNA interactions (El-Deiry et al. 1992; Funk et al. 1992).

A number of mutant forms of p53 interfere with the suppressor function of endogenous wild-type p53 and cause tumors. These mutations cluster in hot spots in the center of the polypeptide chain (Hollstein et al. 1991; Levine et al. 1991) and overlap segments of the protein that are highly conserved among a wide variety of species (Soussi et al. 1990). The position of the oncogenic mutations probably reflects a selective pressure in tumors to inactivate functions crucial to the negative regulation of cell proliferation. This idea is consistent with the finding that most transforming mutations severely reduce site-specific DNA binding (Bargonetti et al. 1991; Kern et al. 1991; El-Deiry et al. 1992) and trans-activation (Raycroft et al. 1990; Raycroft et al. 1991; Farmer et al. 1992; Kern et al. 1992; Unger et al. 1992; Zambetti et al. 1992). Aside from the identification of transforming mutations, mutational analysis of $\mathrm{p} 53$ has been limited. The first 73 amino acids are highly acidic and contribute to the activation of transcription (Fields and Jang 1990; Raycroft et al. 1990). The carboxy-terminal region is moderately basic, and mutations in this region reduce nonspecific DNA binding and oligomerization (Foord et 
al. 1991; Milner et al. 1991; Sturzbecher et al. 1992). Furthermore, Sturzbecher et al. (1992) have shown that carboxy-terminal segments of p53 can oligomerize.

Recently, we investigated the suppression, transformation, and trans-activation functions of isolated segments of wild-type murine p53 (Reed et al. 1993). Intact p53 suppressed cellular transformation by the activated Ras and adenovirus E1A proteins, but deletion of the amino-terminal trans-activation domain blocked suppression. Nevertheless, the trans-activating domain of herpesvirus protein VP16 was able to substitute for the amino-terminal trans-activating domain of p53 in cellular suppression. Thus, unless the interchanged $\mathrm{p} 53$ and VP16 acidic segments share additional functions, transactivation is required for suppression by $\mathrm{p} 53$. Consistent with the studies of Shaulian et al. (1992), we also found that small carboxy-terminal p53 segments containing amino acids $320-360$ enhanced transformation by Ras and E1A, whereas no p53 segments lacking amino acids 320-360 transformed cells. An overlapping region has been associated with the oligomerization of p53 (Milner et al. 1991; Sturzbecher et al. 1992). Intact p53 and chimeric VP16-p53 trans-activated the CAT gene under control of a p53-specific promoter, whereas transforming segments of p53 interfered with trans-activation by wildtype p53. These findings argue strongly that trans-activation by $\mathrm{p} 53$ is required for cellular suppression and that any non-trans-activating $\mathrm{p} 53$ that retains the capacity to oligomerize with wild-type p 53 would have transformation potential. In the present study, we have investigated the oligomerization, DNA-binding, and trans-activation functions of p53 segments. We find that $\mathrm{p} 53$ has two autonomous DNA-binding regions, one that is both specific and nonspecific, and the other that is apparently nonspecific. The specific DNA-binding domain does not form stable tetramers but supports the trans-activation function of $\mathrm{p} 53$ in vivo.

\section{Results \\ Purification of p53 segments}

We wanted to identify autonomous DNA-binding domains of p53 to develop a better understanding of p53 suppression of cellular proliferation. We used an existing collection of p53 segments that was previously used to investigate the suppression and transformation functions of $\mathrm{p} 53$ (Fig. 1A). The p53 segments are identified by their amino acid components, which are numbered according to Pennica et al. (1984). In previous studies, where the relatively weak Moloney sarcoma virus (MSV) promoter was used for p53 expression in animal cells (Reed et al. 1993), segments $1-320$ and 80-320 neither suppressed nor enhanced transformation significantly while segments $80-390,280-390,315-390$, and 315-360 enhanced transformation. We moved these p53 segments and an additional segment, 1-360, into baculovirus expression vectors to overproduce the p53 segments with small amino-terminal tags containing 6 histidine residues for purification by metal-affinity chromatography. Figure 1B shows the purified protein fragments after SDS-gel electrophoresis and Coomassie blue staining. Although the proline- and histidine-rich amino-terminal tag slows the migration of all segments, the p53 segments have the expected relative gel migrations. The smaller segments are resolved into two species; only the upper species is phosphorylated (data not shown).

\section{Phosphorylation of p53 made in insect cells}

We determined that wild-type, untagged p53 made in insect cells is phosphorylated in a pattern similar to that described previously for p53 made in animal cells. Figure 2 shows a two-dimensional tryptic peptide map of purified wild-type p53 radiolabeled in baculovirus-infected cells. The labeled peptides closely resemble peptides of
A

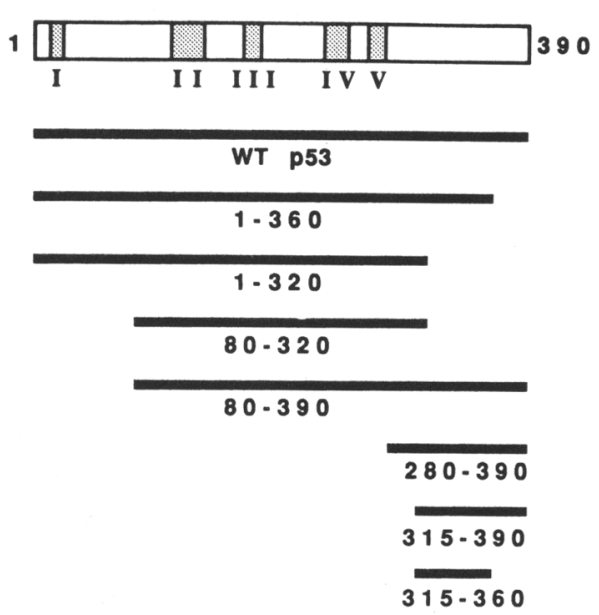

B

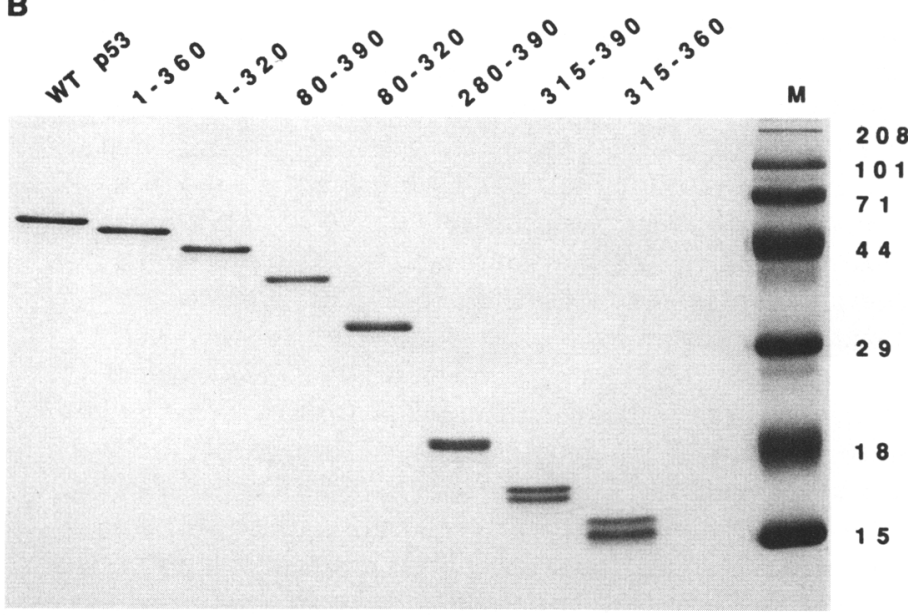

Figure 1. Segments of p53. (A) Map of segments relative to conserved regions of $\mathrm{p} 53$. The solid lines represent p53 segments expressed by different plasmids. $(B)$ p53 segments purified from insect cells infected with recombinant baculoviruses as described in Materials and methods. (Lane $M$ ) The positions of molecular mass standards. 


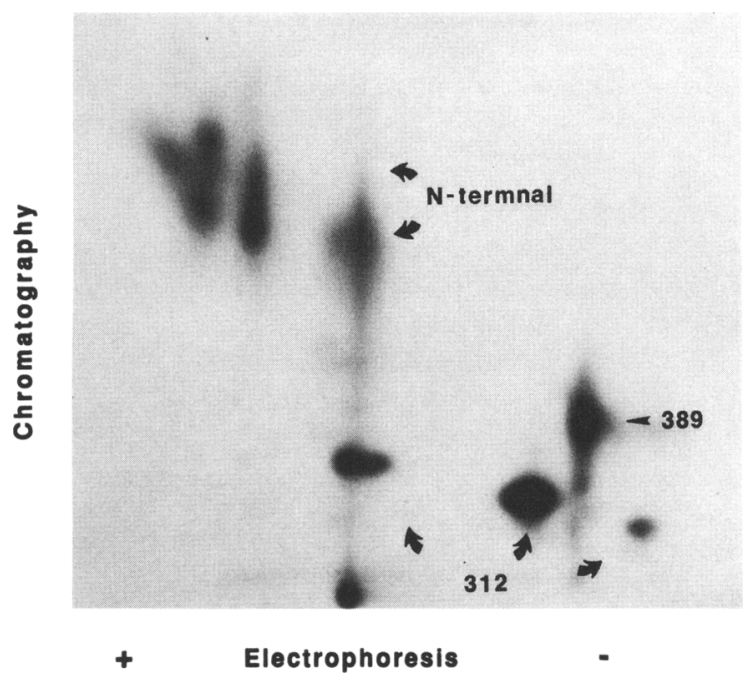

Figure 2. Peptide map of wild-type murine p53 made in insect cells. Purified protein labeled with ${ }^{32} \mathrm{P}$ was digested with trypsin and analyzed in two dimensions as described in Materials and methods. Phosphopeptides are identified.

murine p53 made in animal cells; the phosphopeptides have been identified on the basis of the predicted behavior of the appropriate peptides during electrophoresis and chromatography (Meek and Eckhart 1990). Because the amino-terminal peptides have multiple phosphorylation sites and a complex pattern of phosphorylation, we have not identified individual amino-terminal phosphopeptides. We conclude, however, that p53 made in insect cells is phosphorylated in a pattern similar to that seen in animal cells.

\section{Oligomerization of purified p53 segments}

Previously, we used chemical cross-linking coupled with SDS-gradient gel electrophoresis to show that purified wild-type p53 forms tetrameric structures (Stenger et al. 1992). Figure 3 shows that the p53 segment from amino acids $80-320$ forms only monomers under these experimental conditions regardless of the concentration of $\mathrm{gl}$ utaraldehyde used to cross-link the preparations. The migration of segment 80-320 during SDS-gel electrophoresis increases with increasing glutaraldehyde concentrations. This finding confirms that the cross-linking reaction was successful and resulted in a more compact intramolecular structure. Furthermore, the absence of oligomers of segment $80-320$ shows that the cross-linking conditions did not lead to artifactual intermolecular cross-linking under these conditions. In the absence of glutaraldehyde, the 280-390 segment electrophoresed as a monomer in the SDS-gel. At concentrations of 0.001$0.01 \%$ glutaraldehyde, p53 tetramers were only partially cross-linked and, therefore, partially dissociated during SDS-gel electrophoresis. Monomers, dimers, trimers, and tetramers were evident under these conditions and had the expected molecular masses (molecular mass markers not shown). At higher glutaraldehyde concentrations, preformed tetramers of segment $280-390$ were fully cross-linked and were not dissociated by the SDSgel buffer at all. Under these conditions, p53 segment 280-390 formed tetramers and only tetramers. The complete absence of other oligomeric forms confirms that the glutaraldehyde did not cause artifactual intermolecular cross-linking. We conclude that p53 segment 80320 does not form stable tetramers under the same conditions that favor the efficient tetramerization of segment 280-390. Our findings do not exclude the possibility that p53 segment $80-320$ can form oligomers under less stringent conditions or in the presence of DNA.

\section{DNA binding by wild-type p53}

We examined DNA binding by wild-type p53 using a mobility retardation assay. We used a similar specific DNA substrate and the same binding conditions as those described by Hupp et al. (1992). However, we used phosphorylated murine p53 made in insect cells, whereas Hupp et al. (1992) used unphosphorylated human p53 made in bacterial cells. In addition, our proteins were purified without denaturation. We also used a small double-stranded DNA that contains no known p53 recognition sequences as a probe and as a nonspecific competitor. When used as a nonspecific competitor, this DNA had characteristics similar to those of poly[d(A-T)] and poly[d(I-C)] (data not shown). Because Hupp et al. (1992) showed that pAb421 enhances the DNA binding of wildtype p53, we added the monoclonal antibody to selected samples.

Figure 4 demonstrates the specificity of our assay. In Figure $4 \mathrm{~A}$ we added a $25 \mathrm{M}$ excess of p53 to the p53 recognition sequence 5'-AGACATGCCTAGACATGCCT$3^{\prime}$ within a labeled, 28-bp synthetic DNA. In the absence of pAb421 and competitor DNA, wild-type p53 retarded

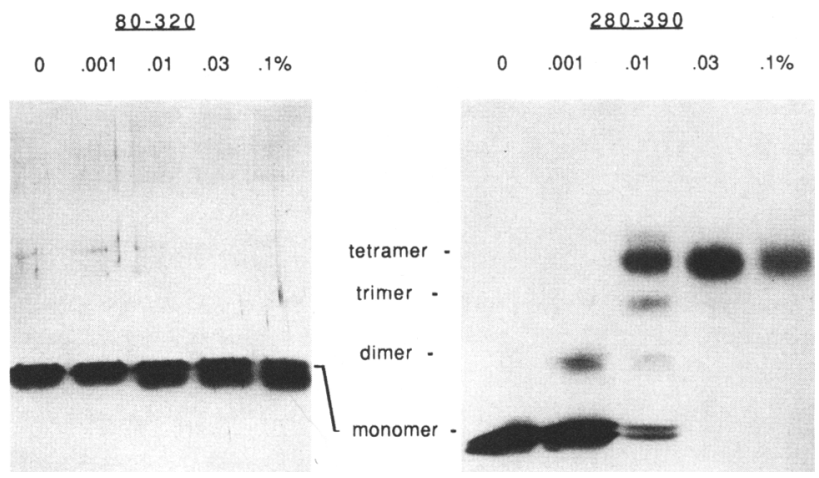

Figure 3. Analysis of the quaternary structures of p53 segments $80-320$ and $280-390$. Purified proteins were examined by SDS-gradient gel electrophoresis without cross-linking and after partial or complete cross-linking at the glutaraldehyde concentrations shown. The positions of monomers, dimers, trimers, and tetramers were determined by molecular mass standards (not shown). 
Wang et al.

A. labeled specific DNA

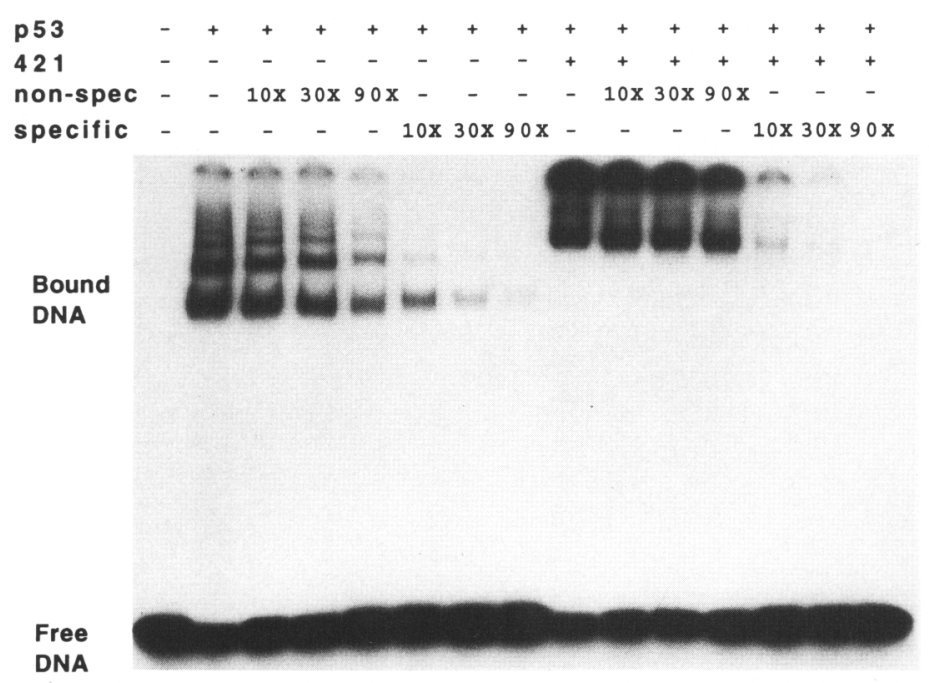

B. labeled nonspecific DNA

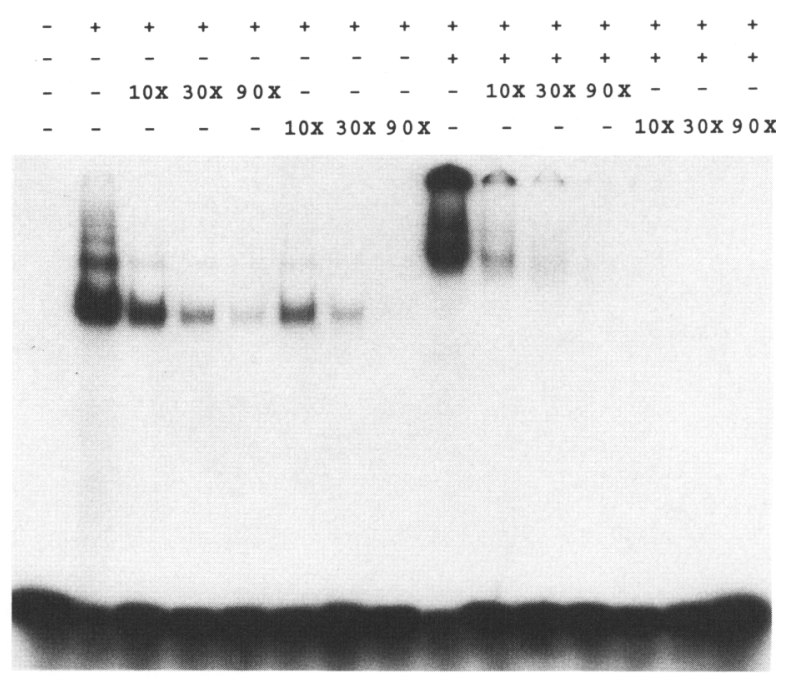

Figure 4. DNA binding by purified wild-type p53 made in insect cells. Protein-DNA complexes were identified by the mobility retardation assay described in Materials and methods. $(A)$ The labeled probe is specific DNA. $(B)$ The labeled probe is nonspecific DNA. p53 (100 ng) was incubated with labeled probe $(2 \mathrm{ng}$ ) in the presence or absence of nonspecific and specific competing DNA. The amount of competing DNA is indicated. pAb421 was added to selected samples as indicated.

the migration of the labeled specific probe to multiple positions in the gel. These complexes were only partially competed by 10 - to 90 -fold excesses of nonspecific double-stranded DNA but were efficiently competed by specific DNA. In the presence of pAb421, p53 retarded the labeled probe more efficiently and caused a supershift to higher positions in the gel. DNA binding was not significantly competed by nonspecific DNA but was inhibited almost completely by specific DNA. p53 binding, therefore, is specific in the absence of pAb421, but the specificity is enhanced in the presence of pAb421. In Figure 4B we used a small, double-stranded DNA containing no p53 recognition sequence as the labeled probe for DNA binding. Wild-type 553 retarded migration of the nonspecific DNA to multiple positions in the gel, and pAb421 caused a supershift in the gel and enhanced binding as it did in the case of specific DNA. Binding to the nonspecific probe, however, was inhibited significantly by nonspecific DNA in either the absence or presence of pAb421. As expected, the specific DNA was somewhat more effective as a competitor.

We conclude that intact wild-type p53 binds DNA in multiple species, that binding is both specific and nonspecific, and that pAb421 enhances binding. These conclusions are consistent with and extend the findings of Hupp et al. (1992), who used nonspecific labeled DNA rather than serial competition studies as a control for specificity.

\section{DNA binding by $p 53$ segments}

We used the mobility retardation assay to determine the specific and nonspecific DNA-binding characteristics of p53 segments (Fig. 5). For the sake of consistency, we initially added pAb421 to all binding reactions even though most of the p53 segments have no corresponding epitope. The specific and nonspecific DNAs were the same synthetic DNAs used in the experiments described above (Fig. 1). Wild-type p53 bound DNA specifically, as shown in Figure 4. Segment 80-390, containing the pAb421 epitope, bound DNA with the same characteristics as wild-type p53. Specific, but not nonspecific competitor, inhibited binding to the specific labeled probe. Segment 280-390, which has the pAb421 epitope, failed to bind to the specific DNA fragment in the presence of pAb421. Segments consisting of amino acids 315-390 and 315-360 also failed to bind DNA (data not shown). Segment 1-360, which has no pAb421 epitope, bound the specific probe in multiple species, and the binding was inhibited much more efficiently by specific than by nonspecific competitor. Surprisingly, segments 1-320 and 80-320, which lack both a pAb421 epitope and a carboxy-terminal tetramerization domain, bound DNA specifically to the same extent as wild-type p53 did at this protein concentration. Additional assays will be required to compare the binding affinities of the proteins. We conclude that the large conserved central region of $\mathrm{p} 53$ is sufficient for specific DNA binding in the absence of stable tetramerization.

There were qualitative differences in the patterns of gel retardation by wild-type p53 and various p53 segments. In contrast to the wild-type protein (Figs. 4 and 5 ) and segment 1-360 (Fig. 5), the 1-320 and 80-320 segments failed to bind DNA as multiple species. Surprisingly, segment 80-320 retarded DNA to a position similar to that of the lowest species of DNA bound to segment 1-360 even though the p53 segments are significantly different in mass. These findings could 


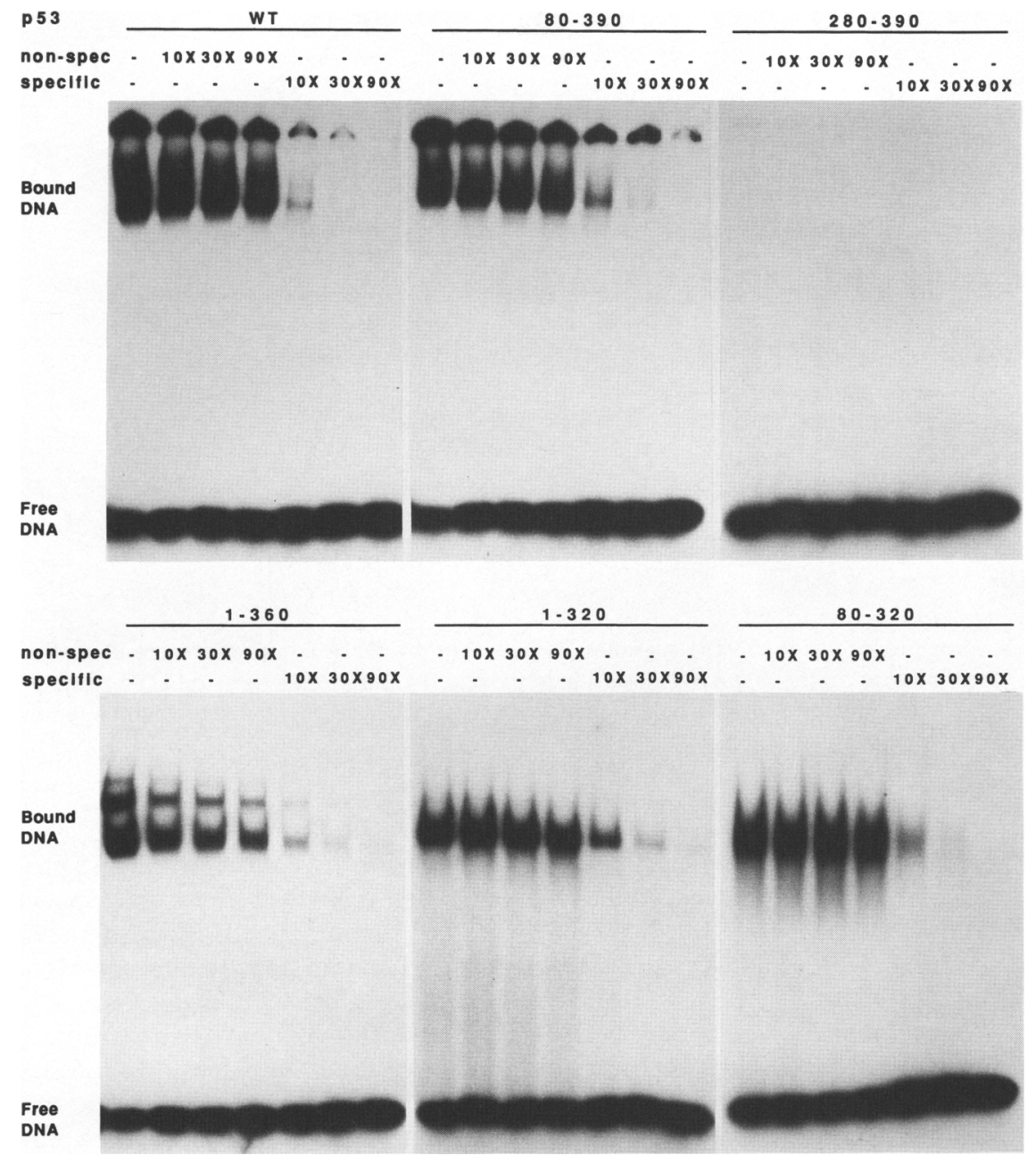

Figure 5. DNA binding by purified wildtype p53 and segments of p53. ProteinDNA complexes were identified by the mobility retardation assay described in Materials and methods. The labeled probe is specific DNA. p53 (100 ng) was incubated with labeled probe $(2 \mathrm{ng})$ in the presence or absence of nonspecific and specific competing DNA. The amount of competing specific or nonspecific DNA is indicated. pAb421 was added to all samples. mean that four subunits of segment $80-320$ bind the p53 recognition sequence. Alternatively, charge and shape differences in segment $80-320$ could slow the electrophoretic migration of single subunits of segment 80-320 bound to DNA. Clearly, the absence of the acidic and proline-rich amino-terminal region would cause significant differences in the charge and possibly the shape of segment 80-320 relative to segment 1-360.

We repeated selected assays in the presence and absence of pAb421 (Fig. 6). The binding of wild-type p53 was specific in the absence of pAb421 and was enhanced by pAb421. These results reproduce those shown in Figures 4 and 5 . As expected, pAb421 had no effect on the binding of p53 segments $1-360$ or $80-320$, which lack the appropriate epitope. Competition analysis indicated that binding by these two fragments was highly specific. In the absence of pAb421, segments 280-390 and 315390 bound DNA. In contrast to binding by wild-type p53, pAb421 almost completely blocked the DNA binding of segments $280-390$ and 315-390. The fact that both nonspecific and specific competitors inhibited binding to similar extents in the absence of pAb421 indicates that binding by the carboxy-terminal fragments was nonspe- cific. Segment 315-360 failed to bind DNA in either the absence or the presence of pAb421. We conclude that amino acids 315-390 have an autonomous, nonspecific, DNA-binding domain that can be blocked by the monoclonal antibody pAb421.

\section{Fine mapping of the specific DNA-binding domain}

We identified the amino- and carboxy-terminal boundaries of the DNA-binding domain by progressively shortening the p53 segment from either end (Fig. 7). We overexpressed the segments in bacteria and purified them using metal-affinity chromatography. After confirming that segment 80-320 made in bacterial and insect cells has the same DNA-binding characteristics (data not shown), we determined the DNA-binding efficiency of the truncated polypeptides with the mobility retardation assay. Figure 7 shows our results, where selected truncation mutants smaller than segment 80-320 were used. The p53 segment from amino acid 80 to 320 served as a positive control for p53-specific DNA binding in the absence of pAb421. It bound the specific DNA probe and retarded its migration to a single position in the gel. 

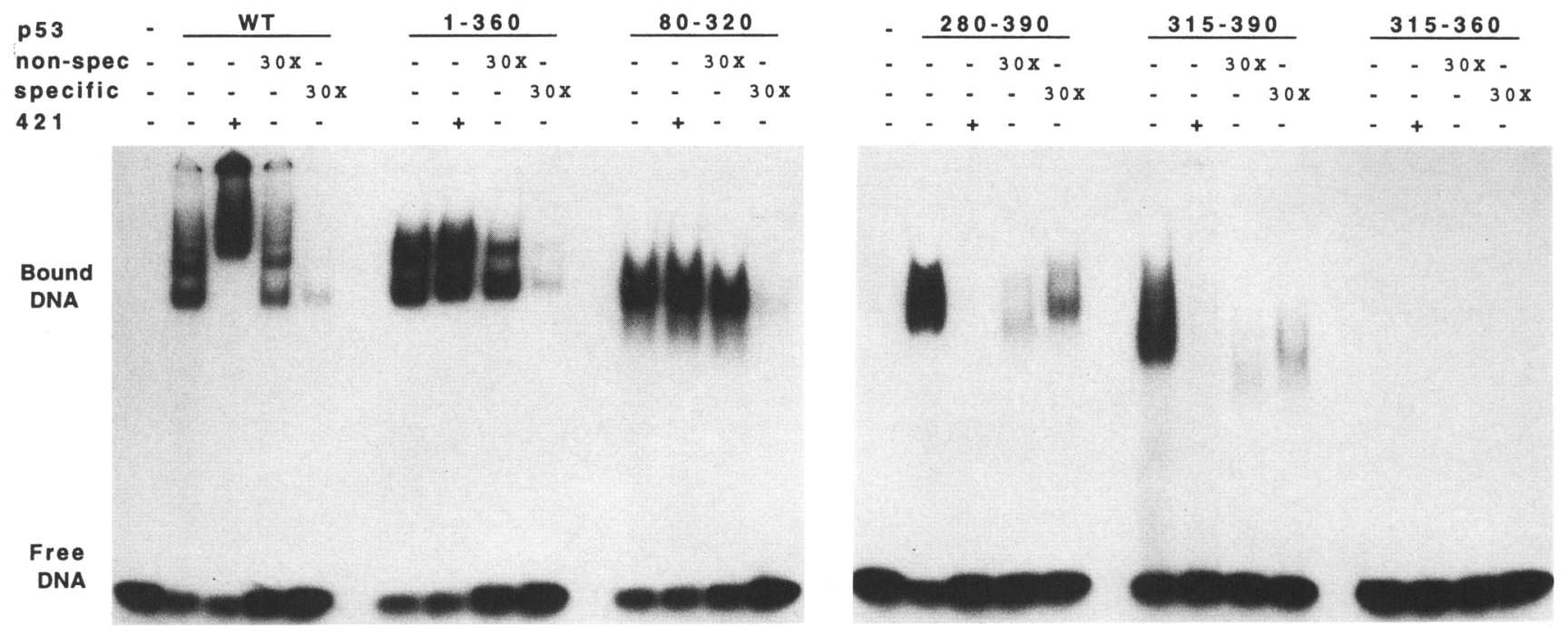

Figure 6. The effects of pAb421 on the DNA-binding properties of p53 and segments of p53. Protein-DNA complexes were identified by the mobility retardation assay described in Materials and methods. pAb421 was added to selected samples as indicated. The labeled probe is specific DNA. p53 (100 ng) was incubated with labeled probe $(2 \mathrm{ng}$ ) in the presence or absence of nonspecific and specific competing DNA. The amount of competing specific or nonspecific DNA is indicated.

Binding was not significantly inhibited by a 30 -fold excess of nonspecific competitor but was completely inhibited by the same concentration of specific competitor. p53 segment $80-290$ behaved in an identical way except that it retarded migration of the specific probe to a lower position in the gel. In contrast, p53 segments 80-260 and 110-320 failed to bind DNA under these conditions. Smaller segments $(140-320,160-320$, 80-230, 110-290, and 140-260) also failed to bind DNA at these protein concentrations (data not shown). We conclude that the minimal, specific DNA-binding domain of p53 is included within segment $80-290$ but not in the smaller segments that we tested. This autonomous DNA-binding region contains the entire highly conserved central region of $\mathrm{p} 53$.

\section{Trans-activation by $p 53$ domains}

We investigated trans-activation by wild-type p53 and segments of p53 to determine how the trans-activation function correlates with the DNA-binding functions (Fig. 8A). We used the chloramphenicol acetyl transferase (CAT) gene under the control of a p53-specific promoter as a reporter for trans-activation. Kern et al. (1992) have shown that 13 DNA recognition sequences for p53 upstream from a TATA sequence act as a strong promoter. We used a reporter plasmid with two copies of this segment upstream from a TATA sequence and the CAT gene. We cotransfected plasmids that express wildtype p53 or segments of p53 and the reporter plasmid into the H358 cell line that is null for p53 function (Funk et al. 1992). Transfection of the control plasmid pCMH6K did not induce the trans-activation of the reporter CAT plasmid $(<500 \mathrm{cpm}$ ). Wild-type p53 stimulated CAT activity $\sim 190$-fold above background. In the absence of the p53 recognition sequences in the test promoter, wild-type p53 failed to induce any transcription of the CAT gene (data not shown). The 1-320 and 1-290 segments stimulated CAT expression by the complete promoter $\sim 90$ - and 40-fold, respectively. In contrast, segments $1-260,80-320$, and $280-390$ failed to stimulate the reporter promoter. We conclude that the autonomous, specific DNA-binding segment is sufficient for strong trans-activation in vivo if it is joined to the amino-terminal acidic region. This experiment provides the best possible evidence that segments $1-320$ and 1-290 are expressed in animal cells and bind specific DNA sequences in vivo under physiological conditions.

We used a combination of metal-affinity selection and immunoblotting techniques to establish p53 expression levels in cells transiently transfected by plasmids expressing p 53 under the control of the cytomegalovirus (CMV) promoter (Fig. 8B). The immunoblot demonstrates that with the exception of segment 1-260, the p53 segments are expressed at significant levels and that the segments have appropriate sizes. Therefore, with the possible exception of segment 1-260, levels of trans-activation reflect intrinsic protein function rather than protein accumulation. Because segment $1-260$ is either insoluble or does not accumulate intracellularly, however, the precise carboxy-terminal limit of the DNAbinding region required for trans-activation cannot be determined with certainty. More importantly, it is clear that segment 1-290 is sufficient for both DNA binding and trans-activation.

\section{Discussion}

We have investigated the oligomerization, DNA-binding, and trans-activating properties of isolated segments 


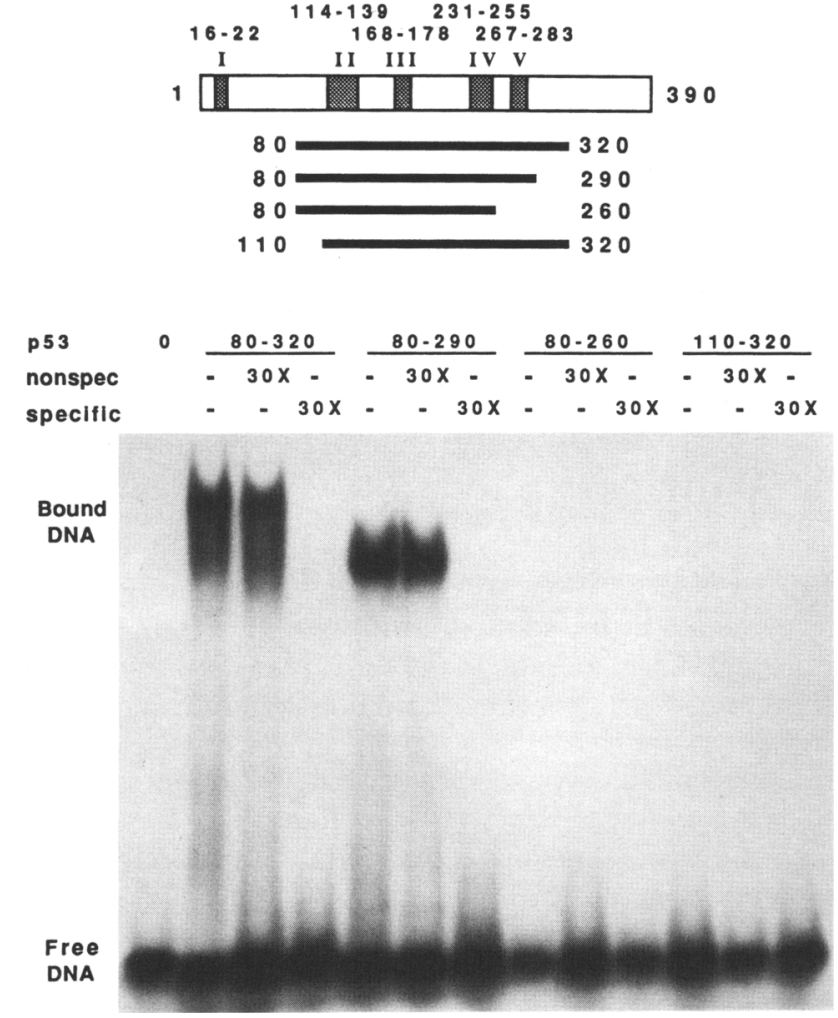

Figure 7. Fine mapping of the specific DNA-binding domain of p53 using truncations of the p53 segment $80-320$. The p53 truncated segments and their positions relative to the most highly conserved regions of p53 are shown at the top. Protein-DNA complexes were identified by the mobility retardation assay described in Materials and methods. The labeled probe is specific DNA. p53 (100 ng) was incubated with labeled probe ( $2 \mathrm{ng}$ ) in the presence or absence of nonspecific and specific competing DNA. The amount of competing specific or nonspecific DNA is indicated.

of wild-type murine $\mathrm{p} 53$. We find that the protein has two autonomous DNA-binding domains. These domains map within amino acids 315-390 and 80-290. Shortening of the domains from either end by $30-35$ amino acids causes loss of their DNA-binding functions.

The 315-390 domain appears to recognize DNA nonspecifically. These findings are consistent with reports that mutations in the carboxyl terminus reduce nonspecific DNA binding (Foord et al. 1991). Because this binding is blocked by pAb421, it is distinct from the specific and nonspecific DNA-binding functions of the intact protein that are stimulated by pAb421. We do not know the function, if any, of this autonomous domain. It could be an artifact of our assay and of no biological significance. Its close association with the tetramerization domain of p53, however, leads us to suspect that it may be important to $\mathrm{p} 53$ function. Nonspecific DNA-binding by p53 tetramers could explain the ability of p53 to promote the annealing of complementary single-stranded nucleic acids. Oberosler et al. (1993) have suggested that this function may play a role in DNA repair or replication.
Alternatively, this nonspecific DNA-binding activity may even be associated with a specific DNA-binding activity distinct from that already identified by many groups. Weissker et al. (1992) have presented evidence that $\mathrm{p} 53$ may have a second specific DNA recognition site. Lambda phage integrase, which has autonomous DNA-binding domains that recognize two different sequence families, provides a precedent for this possibility (Moitoso de Vargas et al. 1988).

The second autonomous domain from amino acids 80290 lacks the carboxy-terminal tetramerization domain but binds DNA both specifically and nonspecifically. Therefore, a major DNA-binding function of p53 resides in the highly conserved central region of $\mathrm{p} 53$. These results are consistent with reports that p53s encoded by mutant DNAs isolated from human tumors are defective for specific and nonspecific DNA binding (Bargonetti et al. 1991; Kern et al. 1991; El-Deiry et al. 1992). These mutant $\mathrm{p} 53 \mathrm{~s}$ have missense mutations in the conserved central region of p53. p53 segment 80-290 contains no obvious conventional DNA-binding motif, but the conformation of this region is highly sensitive to amino acid

\section{A Transactivation}

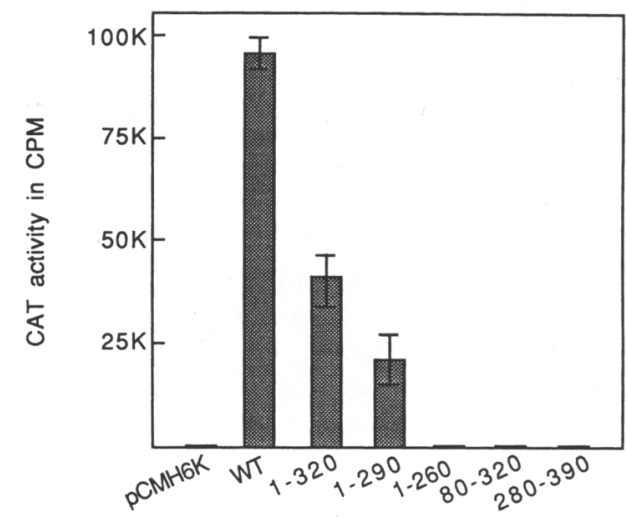

B Protein Expression

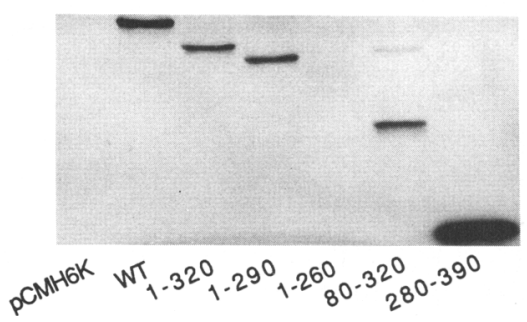

Figure 8. (A) Trans-activation by wild-type p53 and segments of p53. H358 cells were transfected with plasmids expressing the CAT gene under the control of a p53-specific promoter and wild-type p53 or segments of p53. The histogram shows levels of CAT activity induced by the various p53s. $(B)$ Expression of tagged p53. H358 cells were transfected with plasmids expressing wild-type p53 or segments of p53. The tagged p53s were concentrated by metal-affinity selection and analyzed by immunoblotting with monoclonal antibodies against the hemagglutinin tag as described in Materials and methods. 
substitutions and to the binding of antibody to distant sites (Gannon et al. 1990; Hupp et al. 1992). A similar region of $\mathrm{p} 53$ is necessary for the binding of SV40 large $\mathrm{T}$ antigen (Ruppert and Stillman 1993). This overlap in p53 functions would explain how large $T$ antigen blocks the binding of p53 to DNA (Bargonetti et al. 1992). Because the optimal DNA recognition sequence for p53 consists of four imperfect repetitions, it has been proposed that the sequences would accommodate binding by a p 53 tetramer (El-Deiry et al. 1992; Funk et al. 1992). It is therefore somewhat surprising that the central domain maintains significant DNA-binding function in the apparent absence of p53 tetramerization. Perhaps the conformation of this domain, rather than tetramerization, contributes to the affinity of the protein-DNA interaction. We find that pAb246, specific for wild-type p53 (Gannon et al. 1990), reacts with p53 segments that bind DNA specifically but not with segments that fail to bind DNA (data not shown). Other investigators have suggested that the conformation in the conserved region of $\mathrm{p} 53$ may depend on zinc binding (Hainaut and Milner 1993) or a reactive sulfhydryl group (Hupp et al. 1993).

In agreement with others (Funk et al. 1992; Hupp et al. 1992), we have shown that pAb421 increases the specificity of DNA binding by p53. Hupp et al. (1992) interpreted this finding to mean that the binding of pAb421 to the carboxyl terminus of p53 leads to conformational changes that enhance DNA binding. Our data are consistent with that interpretation and offer an addtional explanation for enhancement by pAb421. By interfering with nonspecific binding by the carboxyl terminus, pAb421 may make more p53 available for specific binding by the central domain of p53. Possibly, a similar competition between p53 DNA-binding domains in vivo may play a role in regulation of p53 function. Investigation of this possibility will require a better understanding of the carboxy-terminal DNA-binding function.

Wild-type p53 and some p53 segments that tetramerize form multiple species with both specific and nonspecific DNA in the mobility retardation assay. At the same protein concentrations, segments $80-290$ and 80-320, which do not form stable tetramers, bind DNA as a single species. In theory, the multiple protein-DNA species could represent binding of multiple proteins to a single DNA, structural changes in p53-DNA complexes, binding of a single protein to multiple DNAs, or a combination of these interactions. Because wild-type p53 seems to form predominantly tetrameric forms, we think it unlikely that the multiple species represent binding by monomers, dimers, and tetramers. It also seems improbable that multiple tetramers could bind the small 28-bp DNA probes. Oberosler et al. (1993) have shown that $\mathrm{p} 53$ promotes annealing of complementary single-stranded DNAs. Thus, the possibility that p53 may induce structural changes in DNA cannot be excluded. All the data presented here, however, are consistent with the possibility that tetramers can bind multiple DNAs while monomers with a single DNA interaction site can bind only single DNA molecules. The number of DNAs in the complexes would clearly influence gel mobilities of the complexes.

The DNA-binding properties of the 80-290 domain have biological significance. Expression of amino acids $1-290$ and $1-320$ results in strong activation of a reporter CAT gene in vivo. The reporter gene has $\mathrm{p} 53$ recognition sequences upstream from a TATA box, and deletion of these DNA recognition sequences results in loss of CAT expression. Our p53 segments that lack either the amino-terminal acidic region or the central DNA-binding domain of p53 fail to trans-activate completely. In contrast, p53 segments 1-290 and 1-320, which lack known tetramerization sequences, bind to DNA and activate p53-responsive promoters. Our findings are consistent with those of Aoyama et al. (1992), who showed that human p53 segment 1-326 lequivalent to amino acids $1-323$ in the mouse) is sufficient for trans-activation, and those of Shaulian et al. (1993), who showed that mutation of the carboxy-terminal oligomerization domain does not block trans-activation. We have presented evidence previously that trans-activation is necessary for the suppression of transformation (Reed et al. 1993). Deletion of the p53 acidic region within amino acids $1-80$ completely abolished p53 suppression of transformation by E1A and Ras. Substitution of the trans-activation domain of herpesvirus VP16 for the p53 acidic region fully restored the suppression function. Aside from a net negative charge, the amino acid sequences of the acidic regions of VP16 (Pellet et al. 1985) and p53 (Soussi et al. 1990 ) are quite different. Recent evidence, however, indicates that the acidic regions of both p53 and VP16 interact with the replication protein RF-A (Dutta et al. 1993; Li and Botchan 1993). Thus, unless RF-A binding is needed for suppression, our earlier findings implicate trans-activation in the suppression of cellular proliferation by $\mathrm{p} 53$.

Because p53 segment 1-290 has no carboxy-terminal nuclear localization signals (Shaulsky et al. 1990), it is surprising that it trans-activates a transfected promoter in vivo. Shaulsky et al. (1991) have presented evidence that mutation of the nuclear localization signals blocks suppression of transformation by wild-type p53 expressed under the control of the Moloney murine leukemia virus promoter. In contrast, Slingerland et al. (1993) report that when expressed by the strong CMV promoter, nuclear translocation-defective p53 proteins retain suppressor functions. Because suppression requires trans-activation, this latter study, in support of our present data, indicates that the carboxy-terminal nuclear localization signals of p53 may not be absolutely essential for transactivation. It remains to be determined how p53, apparently lacking a nuclear localization signal, accomplishes trans-activation. Perhaps, the overexpression of p53 under the control of the strong CMV promoter allows a small fraction of p53 to enter the nucleus, or p 53 may be transported into the nucleus in association with another protein or in association with the reporter plasmid DNA itself. Alternatively, p53 may activate the p53 reporter plasmid by an indirect mechanism unrelated to the DNA-binding function of p53. Because the promoter in 
the reporter plasmid contains no transcriptionally active sequences in the absence of the p53-binding site, we think this latter alternative is very unlikely.

Figure 9 summarizes the results of this study and that of Reed et al. (1993) and compares the molecular and biological functions of p53 autonomous domains. The protein is divided into three regions with distinct molecular properties. The amino-terminal segment $1-80$ is highly acidic. The large conserved central domain within segment $80-290$ binds to DNA both specifically and nonspecifically but lacks the carboxy-terminal tetramerization sequences. The carboxy-terminal p53 segment 280-390 forms tetramers autonomously and binds to DNA nonspecifically. The molecular activities in the carboxy-terminal domain are necessary and sufficient for cellular transformation in conjunction with other cellular oncogenes. The acidic amino-terminal region and the central DNA-binding regions are necessary and sufficient for efficient trans-activation. We have found that segment 1-360 is sufficient for suppression of transformation by Ras and E1A (data not shown) and that segment $1-320$ is not sufficient for suppression when expressed under the control of the relatively weak MSV promoter (Reed et al. 1993). Because protein levels may influence the suppression function, the precise limits of the suppression domain remain to be determined.

A number of $\mathrm{p} 53$ functions not examined in this study may contribute to the suppression of cellular proliferation. Our trans-activation assay utilizes a minimal promoter consisting of a p53 recognition element and a TATA sequence. Although natural target promoters of p53 (Weintraub et al. 1991; Kastan et al. 1992; Zambetti et al. 1992; Barak et al. 1993; Wu et al. 1993/ have not yet been identified in any detail, they almost certainly contain additional DNA regulatory elements for transcription. It is possible that these elements modify the effects of $\mathrm{p} 53$ binding. Similarly, interactions of p53 with cellular proteins, like mdm2 (Momand et al. 1992; Oliner et al. 1993) or TBP (Seto et al. 1992; Liu et al. 1993; Mack et al. 1993; Ragimov et al. 1993; Truant et al. 1993), may modify the trans-activation or repression of p53-sensitive promoters. Other investigators have suggested that

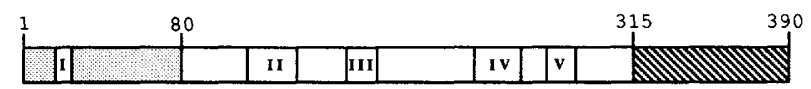

Molecular properties

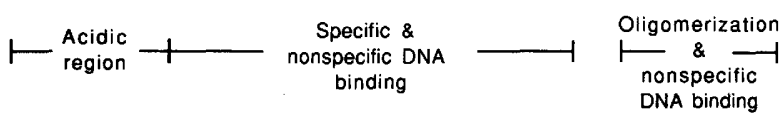

Biological functions

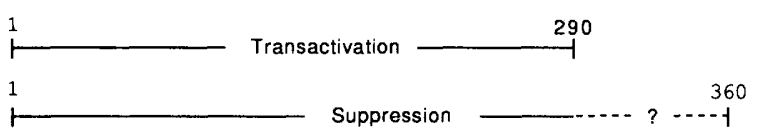

Figure 9. Functional organization of p53. p53 may also play roles in DNA replication (Friedman et al. 1990) and in DNA repair (Lane 1992). Finally, Dittmer et al. (1992) have presented evidence that p53 mutations sometimes confer new or additional phenotypes on cells that express no endogenous p53. The mechanisms underlying these gain-of-function mutations remain unknown. This study not only provides tools for dissecting the molecular activities of p53 but also for relating its activities to regulation of cellular growth.

\section{Materials and methods}

\section{Expression plasmids}

Previously, we have described the pIT plasmid for recombination of $\mathrm{p} 53$ or segments of $\mathrm{p} 53$ with baculovirus and expression in insect cells (Reed et al. 1993). For expression of p53 in bacteria, the DNA cassette used for insertion of PCR-generated DNA segments of p53 in pIT was inserted between the unique NcoI and BamHI sites of pET11d (Dubendorf and Studier 1991) to create the pBT plasmid, which utilizes an inducible T7 promoter for transient expression of $\mathrm{p} 53$. Both plasmids produce p53s with a small amino-terminal tag that encodes six histidines for purification by metal-affinity chromatography (see below).

We constructed the pCMH6K plasmid to express tagged proteins in animal cells. The plasmid includes the following sequences inserted between the ClaI and BamHI sites of pBluescript KS + (Stratagene): the CMV immediate-early promoter from nucleotide -480 to +1 , a cloning and expression cassette flanked by unique NheI and BamHI sites, SV40 small t-antigen splicing signals (SV40 nucleotides 4710-4100), and a polyadenylation signal (SV40 nucleotides 2770-2533). The cloning and expression cassette has a 5'-GCCATGG-3' translation initiation sequence and encodes amino acids MA-YPYDVPDYA / the hemagglutinin epitope)-R-HHHHHH (for metal-affinity chromatography)-A-RRASV (a site for heart creatine kinase A)-GV. Unique $\mathrm{HpaI}$ and BamHI sites allow directional insertion of PCR-generated DNA segments of the murine p53 gene immediately downstream from the cassette. Plasmids were purified by $\mathrm{CsCl}$ centrifugation for transfection studies in animal cells. Expression of the plasmids in animal cells produces p53 with a 26-amino-acid, amino-terminal tag.

\section{Synthesis of p53 domains}

Arnold Levine supplied us with wild-type murine p53 cDNA in pMSVcl (Finlay et al. 1988). We copied the entire p53 sequence or segments of it by using PCR with Vent polymerase (New England Biolabs) as described by the supplier. The PCR primers matched the amino and carboxyl termini of chosen segments of p53. Amino-terminal primers were blunt-ended, and carboxyterminal primers included a termination codon and a BamHI site. The PCR fragments were cut with BamHI and phosphorylated at their 5 ' ends. These fragments were directionally ligated into the cloning and expression cassettes of pIT, pBT, and pCMH6K for expression in insect, bacterial, or animal cells, respectively (see above). The entire sequence of wild-type p53 and amino-terminal junctions of all cloned segments was verified by sequencing. We found no PCR-related mutations. To exclude further the possibility of mutations within p53 segments, we isolated and tested two independent clones expressing each p53 segment. 


\section{Overexpression and metal-affinity purification of p53}

Sf9 insect cells at $80 \%$ confluency in Graces's medium with $10 \%$ fetal bovine serum were infected with high-titer recombinant baculoviruses expressing wild-type p53 or segments of p53. Three days after infection, cell monolayers were removed from plastic $175-\mathrm{cm}^{2}$ flasks by vigorous pipetting and pelleted by low-speed centrifugation. After washing four times with phosphate-buffered saline (PBS) at $4^{\circ} \mathrm{C}$, the pellets were resuspended and lysed in $0.6 \mathrm{ml}$ of lysis buffer ( $150 \mathrm{mM}$ Tris- $\mathrm{HCl}$ at $\mathrm{pH} 9.0$, $150 \mathrm{~mm} \mathrm{NaCl}, 0.5 \% \mathrm{NP}-40,10 \%$ glycerol, $2 \mathrm{mM}$ PMSF, $50 \mu \mathrm{g} /$ $\mathrm{ml}$ of aprotinin, $50 \mu \mathrm{g} / \mathrm{ml}$ of leupeptin, $10 \mu \mathrm{g} / \mathrm{ml}$ of pepstatin A, $2 \mathrm{~mm}$ benzamindine, and $1 \mathrm{~mm} \beta$-mercaptoethanol) for $30 \mathrm{~min}$ on ice. The lysates were cleared by centrifugation at $20,000 \mathrm{rpm}$ in a Sorvall SS-34 rotor at $4^{\circ} \mathrm{C}$ for $30 \mathrm{~min}$. Wild-type p53 or p53 segments with histidine tags were bound to $0.4 \mathrm{ml}$ of Ni-NTAagarose (Qiagen Inc.) in Eppendorf tubes by tumbling overnight at $4^{\circ} \mathrm{C}$. The Ni-NTA-agarose was transferred to a small column and washed eight times with $1 \mathrm{ml}$ of lysis buffer and six times with $1 \mathrm{ml}$ of lysis buffer adjusted to $\mathrm{pH}$ 7.0. The columns were step eluted with lysis buffer at $\mathrm{pH} 7.0$ containing increasing concentrations of imidizole $(25,50,100$, and $250 \mathrm{~mm})$. p53 containing fractions were dialyzed overnight at $4^{\circ} \mathrm{C}$ against $20 \mathrm{mM}$ Tris- $\mathrm{HCl}$ ( $\mathrm{pH} 8.0$ ), $100 \mathrm{~mm} \mathrm{NaCl}$, and $50 \%$ glycerol (dialysis buffer). The proteins were quantitated by gel electrophoresis and Coomassie blue staining and were stored in aliquots at $-70^{\circ} \mathrm{C}$.

Bacterial cells (HMS174 or BL21), transformed by pBT plasmids expressing segments of $\mathrm{p} 53$, were grown from a single colony overnight in $10 \mathrm{ml}$ of Luria broth (LB) medium. After transfer to a $500-\mathrm{ml}$ culture for $4 \mathrm{hr}$ at $37^{\circ} \mathrm{C}$, the cells were induced with IPTG at a final concentration of $1 \mathrm{mM}$ and incubated for $4 \mathrm{hr}$ at $30^{\circ} \mathrm{C}$. The cells were pelleted by centrifugation at $4000 \mathrm{~g}$ for $20 \mathrm{~min}$. The pellets were suspended in $15 \mathrm{ml}$ of lysis buffer and were broken with a French press at 1000 psi. The lysates were cleared by centrifugation and were passed slowly through $0.8 \mathrm{ml}$ of Ni-NTA-agarose in a small column. The bound p53 was washed, eluted, and dialyzed as described above. Purified p53 segments were the only bands seen in gels stained by Coomassie blue.

\section{Peptide mapping of p53}

Baculovirus-infected Sf9 cells were labeled with [ $\left[{ }^{32} \mathrm{P}\right]$ orthophosphate (New England Nuclear) in phosphate-free medium 50-54 hr after infection. Wild-type untagged p53 was extracted and purified by immunoaffinity chromatography as described by Stenger et al. (1992). Tryptic digestion and peptide mapping of wild-type p53 were done as described by Meek and Eckhart (1990).

\section{Oligomerization of $p 53$}

The quaternary structure of p 53 segments was analyzed by protein cross-linking in conjunction with gradient gel electrophoresis as first described by Stenger et al. (1992). Purified p53 segments $\left(3 \mu \mathrm{g}\right.$ ) were incubated for $30 \mathrm{~min}$ at $25^{\circ} \mathrm{C}$ in $30 \mu$ l of p53 dialysis buffer containing various concentrations of freshly diluted glutaraldehyde (Sigma). The products of the cross-linking reactions were analyzed by gel electrophoresis. All of the gel components were those described by Laemmli (1970), except that we used an 80:1 ratio of acrylamide to bis-acrylamide at $\mathrm{pH}$ 8.8 to prevent protein retardation in the stacking gel. The samples were diluted twofold in sample buffer containing $4 \%$ (wt/ vol) SDS and $5 \%(\mathrm{vol} / \mathrm{vol}) \beta$-mercaptoethanol and heated for 5 $\min$ at $100^{\circ} \mathrm{C}$ immediately before being loaded onto the gel. The samples were electrophoresed through 8-20\% polyacrylamide gels in $0.1 \%$ SDS at $200 \mathrm{~V}$ for $4 \mathrm{hr}$ at room temperature. Following electrophoresis, the gels were silver stained (Oakley et al. 1980).

\section{Mobility shift assay for DNA binding by p53}

Completely double-stranded, radiolabeled DNA probes were made by annealing synthetic oligonucleotides and filling their 4-nucleotide overhangs with DNA polymerase. The 28-bp specific probe had the sequence 5'-CCGGAGACATGCCTAGACATGCCTCCGG-3'; the 40-bp nonspecific probe had the sequence 5'-CATGCCATGAAACGCCCCAGGCCAAGGCCTCCCGGGGATC-3'. The same DNAs were used as specific and nonspecific, unlabeled competitor DNAs. Equal amounts of complementary oligonucleotides were annealed in $20 \mathrm{mM}$ Tris ( $\mathrm{pH} 7.4$ ), $2 \mathrm{mM} \mathrm{MgCl}_{2}$, and $50 \mathrm{mM} \mathrm{NaCl}$ at $80^{\circ} \mathrm{C}$ for $10 \mathrm{~min}$ and cooled slowly to room temperature. The annealed oligonucleotides were diluted to $1 \mu \mathrm{g} / \mu \mathrm{l}$ in TE buffer. The probes $(1 \mu \mathrm{g}$ were radiolabeled with $\left[{ }^{32} \mathrm{P}\right] \mathrm{dCTP}$ and $\left[{ }^{32} \mathrm{P}\right] \mathrm{dGTP}$ using the Klenow fragment of DNA polymerase I and ethanol precipitated. Annealed radiolabeled oligonucleotides $(2 \mathrm{ng})$, unlabeled competitor DNA (20-180 ng), and wild-type p53 or segments of p53 (100 ng) were mixed in this order at a final concentration of 25 mM HEPES (pH 7.4), $50 \mathrm{~mm} \mathrm{KCl,20 \%} \mathrm{glycerol,} 0.1 \%$ NP-40, 1 $\mathrm{mM} \mathrm{DTT}$, and $1 \mathrm{mg} / \mathrm{ml}$ of bovine serum albumin. After incubation on ice for $20 \mathrm{~min}, \mathrm{pAb} 421$ was added for $20 \mathrm{~min}$ when appropriate. The samples were loaded onto $4 \%$ polyacrylamide gels and subjected to electrophoresis in $0.3 \times$ TBE in a cold room for $2 \mathrm{hr}$. The gels were dried and exposed to X-ray film overnight at $-70^{\circ} \mathrm{C}$.

\section{CAT assays for $p 53$ trans-activation}

NCI-H358 cells that express no endogenous p53 (Funk et al. 1992) were transfected by using liposome-mediated transfection as described previously (Reed et al. 1993). The reporter plasmid contained 26 direct repeats of a p53 recognition sequence $19 \mathrm{bp}$ upstream from an E1B TATA sequence and the CAT reporter gene. It was constructed by inserting two $\mathrm{PG}_{13}$ recognition segments from $\mathrm{pPG}_{13} \mathrm{CAT}$ (Kern et al. 1992) between the HindIII and PstI sites and a synthetic E1B TATA sequence between the $S a I I$ and $X b a I$ sites of pChlorAce-B (U.S. Biochemical). The pCMH6K plasmids were used to express wild-type p53 or segments of p53. H358 cells were cotransfected with $5 \mu \mathrm{g}$ each of the reporter and p53 expression plasmids. Cells were harvested after $48 \mathrm{hr}$, and CAT activities were measured by phase extraction using a kit and procedures supplied by U.S. Biochemical. Each assay was repeated four times; there was $<25 \%$ variation among transfections of the same plasmid using liposome-mediated transfection.

\section{Immunoprecipitation and immunoblotting}

$\mathrm{H} 358$ cells in two $10-\mathrm{cm}^{2}$ plates were transfected with $20 \mu \mathrm{g}$ of pCMH6K plasmid DNAs expressing wild-type p53 or segments of p53 using calcium-phosphate precipitation (Chen and Okayama 1987). After $30 \mathrm{hr}$, the cells were washed with PBS, and p53 was extracted with $0.5 \mathrm{ml}$ of lysis buffer for $30 \mathrm{~min}$ at $4^{\circ} \mathrm{C}$. The tagged p53s were bound to $100 \mu \mathrm{l}$ of Ni-NTA-agarose (Qiagen Inc.) overnight at $4^{\circ} \mathrm{C}$. After the beads were washed three times with $1 \mathrm{ml}$ of lysis buffer, the tagged p53s were released with $100 \mu$ l of SDS loading buffer for gel electrophoresis. The concentrated and partially purified p53s were analyzed by SDS-gel electrophoresis and immunoblotting using a kit for enhanced chemiluminescence (Amersham). We used $600 \mu \mathrm{g}$ of 
monoclonal antibody in ascitic fluid (12CA5 supplied by Babco) in $100 \mathrm{ml}$ against the hemaglutinin epitope within the aminoterminal tag for the immunoblotting procedure.

\section{Acknowledgments}

This investigation was supported by U.S. Public Health Service grants [National Institutes of Health (NIH)] CA-28146 and CA18808 awarded by the National Cancer Institute. We thank Arnold Levine for $\mathrm{pMSVcl}$ and Bert Vogelstein for $\mathrm{pPG}_{13} \mathrm{CAT}$.

The publication costs of this article were defrayed in part by payment of page charges. This article must therefore be hereby marked "advertisement" in accordance with 18 USC section 1734 solely to indicate this fact.

\section{References}

Aoyama, N., T. Nagase, T. Sawazaki, G. Mizuguchi, H. Nakagoshi, J. Fujisawa, M. Yoshida, and S. Ishii. 1992. Overlap of the p53-responsive element and cAMP-responsive element in the enhancer of human T-cell leukemia virus type I. Proc. Natl. Acad. Sci. 89: 5403-5407.

Barak, Y., T. Juven, R. Haffner, and M. Oren. 1993. mdm2 expression is induced by wild type-p53 activity. EMBO $I$. 12: $461-468$.

Bargonetti, J., P.N. Friedman, S.E. Kern, B. Vogelstein, and C. Prives. 1991. Wild-type but not mutant p53 immunopurified proteins bind to sequences adjacent to the SV40 origin of replication. Cell 65: 1083-1091.

Bargonetti, J., I. Reynisdottir, P.N. Friedman, and C. Prives. 1992. Site-specific binding of wild-type p53 to cellular DNA is inhibited by SV40 T antigen and mutant p53. Genes \& Dev. 6: 1886-1898.

Chen, C. and H. Okayama. 1987. High efficiency transformation of mammalian cells by plasmid DNA. Mol. Cell. Biol. 7: 2745-2752.

Dittmer, D., S. Pati, G. Zambetti, S. Chu, A.K. Teresky, M. Moore, C. Finlay, and A.J. Levine. 1992. Gain of function mutations in p53. Nature Genet. 4: 42-46.

Dubendorf, J.W. and F.W. Studier. 1991. Controlling basal expression in an inducible $\mathrm{T} 7$ expression system by blocking the target T7 promoter with lac repressor. I. Mol. Biol. 219: 45-59.

Dutta, A., J.M. Ruppert, J.C. Aster, and E. Winchester. 1993. Inhibition of DNA replication factor RPA by p53. Nature 365: 79-82.

El-Deiry, W.S., S.E. Kern, J.A. Pietenpol, K.W. Kinzler, and B. Vogelstein. 1992. Human genomic DNA sequences define a consensus DNA binding site for p53. Nature Genet. 1: 4549.

Eliyahu, D., D. Michalovitz, S. Eliyahu, O. Pinhasi-Kimhi, and M. Oren. 1989. Wild-type p53 can inhibit oncogene-mediated focus formation. Proc. Natl. Acad. Sci. 86: 8763-8767.

Farmer, G., J. Bargonetti, H. Zhu, P. Friedman, R. Prywes, and C. Prives. 1992. Wild-type p53 activates transcription in vitro. Nature 358: 83-86.

Fields, S. and S.K. Jang. 1990. Presence of a potent transcription activating sequence in the p53 protein. Science 249: 10461049.

Finlay, C.A., P.W. Hinds, T.-H. Tan, D. Eliyahu, M. Oren, and A.J. Levine. 1988. Activating mutations for transformation by $\mathrm{p} 53$ produce a gene product that forms an hsc 70-p53 complex with an altered half-life. Mol. Cell. Biol. 8: 531-539.

Finlay, C.A., P.W. Hinds, and A.J. Levine. 1989. The p53 protooncogene can act as a suppressor of transformation. Cell
57: 1083-1093.

Foord, O.S., P. Bhattacharya, Z. Reich, and V. Rotter. 1991. A DNA binding domain is contained in the C-terminus of wild-type p53-protein. Nucleic Acids Res. 19: 5191-5198.

Friedman, P.N., S.E. Kern, B. Vogelstein, and C. Prives. 1990. Wild-type, but not mutant, human p 53 proteins inhibit the replication activities of simian virus-40 large tumor antigen. Proc. Nat1. Acad. Sci. 87: 9275-9279.

Friedman, P.N., X.B. Chen, J. Bargonetti, and C. Prives. 1993. The 53 protein is an unusually shaped tetramer that binds directly to DNA. Proc. Natl. Acad. Sci. 90: 3319-3323.

Funk, W.D., D.T. Pak, R.H. Karas, W.E. Wright, and J.W. Shay. 1992. A transcriptionally active DNA-binding site for human p53 protein complexes. Mol. Cell. Biol. 12: 2866-2871.

Gannon, J.V., R. Greaves, R. Iggo, and D.P. Lane. 1990. Activating mutations in $\mathrm{p} 53$ produce a common conformational effect-A monoclonal antibody specific for the mutant form. EMBO I. 9: 1595-1602.

Ginsberg, D., F. Mechta, M. Yaniv, and M. Oren. 1991. Wildtype p53 can down-modulate the activity of various promoters. Proc. Natl. Acad. Sci. 88: 9979-9983.

Hainaut, P. and J. Milner. 1993. A structural role for metal ions in the wild-type conformation of the tumor suppressor protein-p53. Cancer Res. 53: 1739-1742.

Hinds, P., C. Finlay, and A.J. Levine. 1989. Mutation is required to activate the p53 gene for cooperation with the ras oncogene and transformation. J. Virol. 63: 739-746.

Hollstein, M., D. Sidransky, B. Vogelstein, and C.C. Harris. 1991. p53 mutations in human cancers. Science 253: 49-53.

Hupp, T.R., D.W. Meek, C.A. Midgley, and D.P. Lane. 1992. Regulation of the specific DNA binding function of p53. Cell 71: 875-886.

1993. Activation of the cryptic DNA binding function of mutant forms of p53. Nucleic Acids Res. 21: 3167-3174.

Kastan, M.B., Q. Zhan, W.S. El-Deiry, F. Carrier, T. Jacks, W.V. Walsh, and A.J. Fornace. 1992. A mammalian cell cycle checkpoint pathway utilizing p53 and GADD45 is defective in ataxia telangiectasia. Cell 71: 587-597.

Kern, S.E., K.W. Kinzler, A. Bruskin, D. Jarosz, P. Friedman, C. Prives, and B. Vogelstein. 1991. Identification of p53 as a sequence-specific DNA-binding protein. Science 252: 17081711.

Kern, S.E., J.A. Pietenpol, S. Thiagalingam, A. Seymour, K.W. Kinzler, and B. Vogelstein. 1992. Oncogenic forms of p53 inhibit p53-regulated gene expression. Science 256: 827830.

Laemmli, U.K. 1970. Cleavage of structural proteins during the assembly of the head of bacteriophage T4. Nature 227: 680685.

Lane, D.P. 1992. Cancer-p53, guardian of the genome. Nature 358: 15-16.

Levine, A.J., J. Momand, and C.A. Finlay. 1991. The p53 tumour suppressor gene. Nature 351: 453-456.

Li, R. and M.R. Botchan. 1993. The acidic transcriptional activation domains of VP16 and p53 bind the cellular replication protein A and stimulate in vitro BPV-1 DNA replication. Cell 73: 1207-1221.

Liu, X., C.W. Miller, P.H. Koeffler, and A.J. Berk. 1993. The p53 activation domain binds the TATA box-binding polypeptide in holo-TFIID, and a neighboring p53 domain inhibits transcription. Mol. Cell. Biol. 13: 3291-3300.

Mack, D.H., J. Vartikar, J.M. Pipas, and L.A. Laimins. 1993. Specific repression of TATA-mediated but not initiator-mediated transcription by wild-type-p53. Nature 363: 281-283.

Meek, W. and W. Eckhart. 1990. Mutation of the serine 312 phosphorylation site does not alter the ability of mouse p53 
to inhibit simian virus 40 DNA replication in vivo. $J$. Virol. 64: 1734-1744.

Mercer, E., M.T. Shields, D. Lin, E. Appella, and S.J. Ullrich. 1991. Growth suppression induced by wild-type p 53 protein is accompanied by selective down-regulation of proliferating-cell nuclear antigen expression. Proc. Natl. Acad. Sci. 88: 1958-1962.

Milner, J., E.A. Medcalf, and A.C. Cook. 1991. Tumor suppressor p53: Analysis of wild-type and mutant p53 complexes. Mol. Cell. Biol. 11: 11-19.

Moitoso de Vargas, L., C.A. Pargellis, N.M. Hasan, E.W. Bushman, and A. Landy. 1988. Autonomous DNA binding domains of $\lambda$ integrase recognize two different sequence families. Cell 54: 923-929.

Momand, J., G.P. Zambetti, D.C. Olson, D. George, and A.J. Levine. 1992. The mdm-2 oncogene product forms a complex with the p53 protein and inhibits p53-mediated transactivation. Cell 69: 1237-1245.

Oakley, B.R., D.R. Kirsch, and N.R. Morris. 1980. A simplified ultrasensitive silver stain for detecting proteins in polyacrylamide gels. Anal. Biochem. 105: 361-363.

Oberosler, P., P. Hloch, U. Ramsperger, and H. Stahl. 1993. p53catalyzed annealing of complementary single-stranded nucleic acids. $E M B O I$. 12: 2389-2396.

Oliner, J.D., J.A. Pietenpol, S. Thiagalingam, J. Gvuris, K.W. Kinzler, and B. Vogelstein. 1993. Oncoprotein MDM2 conceals the activation domain of tumour suppressor-p53. $\mathrm{Na}$ ture 362: 857-860.

Pellet, P.E., J.L.C. McKnight, F.J. Jenkins, and B. Roizman. 1985. Nucleotide sequence and predicted amino acid sequence of a protein encoded in a small herpes simplex virus DNA fragment capable of trans-inducing $\alpha$ genes. Proc. Natl. Acad. Sci. 82: 5870-5874.

Pennica, D., D.V. Goeddel, J.S. Hayflick, N.C. Reich, C.W. Anderson, and A.J. Levine. 1984. The amino acid sequence of murine p53 determined from a c-DNA clone. Virology 134: $477-482$.

Ragimov, N., A. Krauskopf, N. Navot, V. Rotter, M. Oren, and Y. Aloni. 1993. Wild-type but not mutant-p53 can repress transcription initiation in vitro by interfering with the binding of basal transcription factors to the TATA motif. Oncogene 8: 1183-1193.

Raycroft, L., H. Wu, and G. Lozano. 1990. Transcriptional activation by wild-type but not transforming mutants of the p53 anti-oncogene. Science 249: 1049-1051.

Raycroft, L., J.R. Schmidt, K. Yoas, M.M. Hao, and G. Lozano. 1991. Analysis of p53 mutants for transcriptional activity. Mol. Cell. Biol. 11: 6067-6074.

Reed, M., Y. Wang, G. Mayr, M.E. Anderson, J.F. Schwedes, and P. Tegtmeyer. 1993. p53 domains: Suppression, transformation, and transactivation. Gene Expression 3: 95-107.

Ruppert, J.M. and B. Stillman. 1993. Analysis of a protein-binding domain of p53. Mol. Cell. Biol. 13: 3811-3820.

Santhanam, U., A. Ray, and P.B. Sehgal. 1991. Repression of the interleukin 6 gene promoter by 553 and the retinoblastoma susceptibility product. Proc. Natl. Acad. Sci. 88: 7605-7609.

Seto, E., A. Usheva, G.P. Zambetti, J. Momand, N. Horikoshi, R. Weinmann, A.J. Levine, and T. Shenk. 1992. Wild-type p53 binds to the TATA-binding protein and represses transcription. Proc. Natl. Acad. Sci. 89: 12028-12032.

Shaulian, E., A. Zauberman, D. Ginsberg, and M. Oren. 1992. Identifiation of a minimal transforming domain of p53: Negative dominance through abrogation of sequence-specific DNA binding. Mol. Cell. Biol. 12: 5581-5592.

Shaulian, E., A. Zauberman, J. Milner, E.A. Davies, and M. Oren. 1993. Tight DNA binding and oligomerization are dis- pensable for the ability of p53 to transactivate target genes and suppress transformation. EMBO I. 12: 2789-2797.

Shaulsky, G., N. Goldfinger, A. Benzeev, and V. Rotter. 1990. Nuclear accumulation of P53 protein is mediated by several nuclear localization signals and plays a role in tumorigenesis. Mol. Cell. Biol. 10: 6565-6577.

Shaulsky, G., N. Goldfinger, M.S. Tosky, A.J. Levine, and V. Rotter. 1991. Nuclear localization is essential for the activity of p53 protein. Oncogene 6: 2055-2065.

Shiio, Y., T. Yamamoto, and N. Yamaguchi. 1992. Negative regulation of $\mathrm{Rb}$ expression by the $\mathrm{p} 53$ gene product. Proc. Natl. Acad. Sci. 89: 5206-5210.

Slingerland, J.M., J.R. Jenkins, and S. Benchimol. 1993. The transforming and suppressor functions of p53 alleles-Effects of mutations that disrupt phosphorylation, oligomerization and nuclear translocation. EMBO J. 12: 1029-1037.

Soussi, T., C. Caron de Fromentel, and P. May. 1990. Structural aspects of the p53 protein in relation to gene evolution. Oncogene 5: 945-952.

Stenger, J.E., G.A. Mayr, K. Mann, and P. Tegtmeyer. 1992. Formation of stable p53 homotetramers and multiples of tetramers. Mol. Carcinogen. 5: 102-106.

Sturzbecher, H.-W., R. Brain, C. Addison, K. Rudge, M. Remm, M. Grimaldi, E. Keenan, and J.R. Jenkins. 1992. A C-terminal $\alpha$-helix plus basic region motif is the primary structural determinant of p53 tetramerization. Oncogene 7: 1513-1523.

Truant, R., H. Xiao, C.J. Ingles, and J. Greenblatt. 1993. Direct interaction between the transcriptional activation domain of human p53 and the TATA box-binding protein. $J$. Biol. Chem. 268: 2284-2287.

Unger, T., M.M. Nau, S. Segal, and J.D. Minna. 1992. p53: A transdominant regulator of transcription whose function is ablated by mutations occurring in human cancer. $E M B O \mathrm{~J}$. 11: 1383-1390.

Weintraub, H., S. Hauschka, and S.J. Tapscott. 1991. The MCK enhancer contains a p53 responsive element. Proc. Natl. Acad. Sci. 88: 4570-4571.

Weissker, S.N., B.F. Muller, A. Homfeld, and W. Deppert. 1992. Specific and complex interactions of murine p53 with DNA. Oncogene 7: 1921-1932.

Wu, X.W., J.H. Bayle, D. Olson, and A.J. Levine. 1993. The p53 mdm-2 autoregulatory feedback loop. Genes \& Dev. 7: 1126-1132.

Zambetti, G.P., J. Bargonetti, K. Walker, C. Prives, and A.J. Levine. 1992. Wild-type p53 mediates positive regulation of gene expression through a specific DNA sequence element. Genes \& Dev. 6: 1143-1152. 


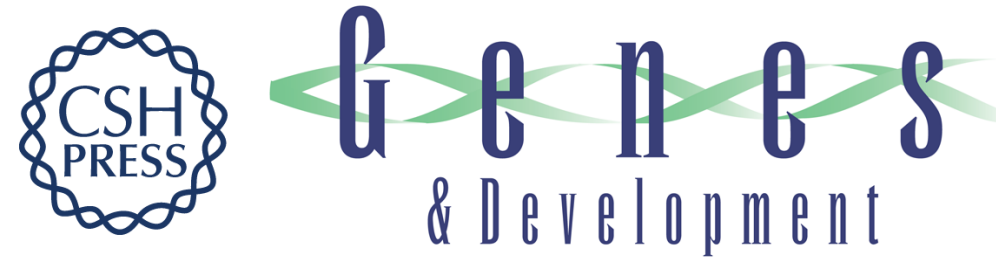

\section{p53 domains: identification and characterization of two autonomous DNA-binding regions.}

Y Wang, M Reed, P Wang, et al.

Genes Dev. 1993, 7:

Access the most recent version at doi:10.1101/gad.7.12b.2575

References This article cites 66 articles, 31 of which can be accessed free at:

http://genesdev.cshlp.org/content/7/12b/2575.full.html\#ref-list-1

License

Email Alerting

Service

Receive free email alerts when new articles cite this article - sign up in the box at the top right corner of the article or click here.

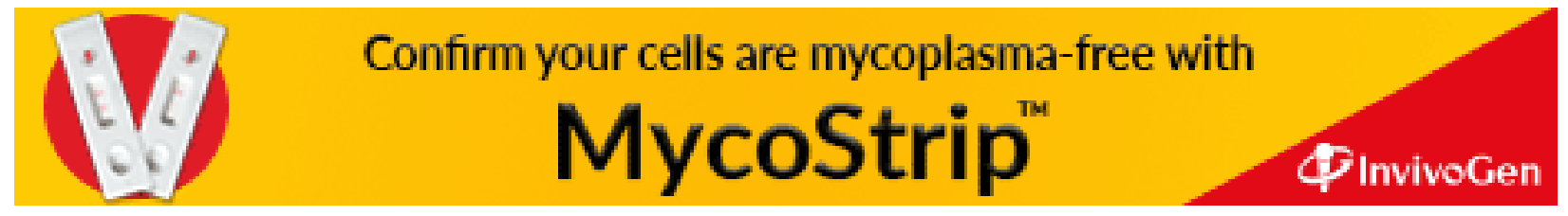

